\title{
EchoGéo
}

39 | 2017

Ressources urbaines (1)

\section{Identifying urban resources to read socio-spatial inequalities}

Introduction

Aurélia Michel and Antonine Ribardière

\section{OpenEdition}

\section{Journals}

Electronic version

URL: https://journals.openedition.org/echogeo/14943

DOI: $10.4000 /$ echogeo. 14943

ISSN: 1963-1197

Publisher

Pôle de recherche pour l'organisation et la diffusion de l'information géographique (CNRS UMR 8586)

Electronic reference

Aurélia Michel and Antonine Ribardière, "Identifying urban resources to read socio-spatial inequalities", EchoGéo [Online], 39 | 2017, Online since 28 March 2017, connection on 10 August 2021. URL: http:// journals.openedition.org/echogeo/14943 ; DOI: https://doi.org/10.4000/echogeo.14943

This text was automatically generated on 10 August 2021

EchoGéo est mis à disposition selon les termes de la licence Creative Commons Attribution - Pas d'Utilisation Commerciale - Pas de Modification 4.0 International (CC BY-NC-ND) 


\title{
Identifying urban resources to read socio-spatial inequalities
}

\author{
Introduction
}

Aurélia Michel and Antonine Ribardière

1 In recent years, academic research has renewed our understanding of the social processes, such as increased inequality, brought along by the intense urbanisation of societies both in the North and the South. This literature qualifies and characterizes the resources at stake in these processes: housing and associated services, employment, education, healthcare, intra-urban transport, mobility ${ }^{1}$ or on the contrary, immobility ${ }^{2}$.

2 These resources can be understood as urban resources - that is, not just as a sum of services but also in terms of their specific spatial distribution over urban space, mutual interaction and conditions of access. According to this approach, a location in the city can be a resource in itself, as can access to a place where potential resources are available. Additionally, qualifying resources on the basis of their location introduces a diachronic dimension: urban resources are the result of a construction process, which happens over time and is driven by public and private stakeholders; they have been subjected to major transformations throughout the history of urban spaces (urban sprawl, economic change, construction of new infrastructure, etc.).

3 Although it can be a challenge to qualify urban resources through objective and quantifiable characteristics, their empirical reality manifests itself through welldocumented situations: for instance, looking at shortages of facilities in certain areas, or at the housing market where such resources are quantified even in the absence of a definition. Beyond a mere inventory of services available to residents, the concept of urban resources can in particular be called upon to qualify situations of social exclusion or poverty, whether looking at individual trajectories or at the spaces that are produced through these processes.

4 Urban resources thus appear as markers of socio-spatial inequality. The dearth of services in socially disadvantaged areas, or on the contrary the density of rare services in more central areas, which create positions of competitive advantage ${ }^{3}$, can be interpreted both as an effect and a cause of the production of inequality. The networks 
that preside over access to housing, the housing stock's structure and the workings of the property market impact and shape the households' residential strategies. On the employment front, the distance between living and work places, the servicing levels and the quality of the networks create barriers to accessing employment for disadvantaged groups (Bertrand, 2010, op. cit.; Wenglenskli S., 2010).

The issue of access to urban resources varies between individuals, depending not only on their own location - with contextual effects combining the specificities of a given neighbourhood and those of the neighbourhood's location within the city ${ }^{4}$ but also on other resources that can be accessed by all - economic resources, mobility, social networks, etc. (Lévy J.-P., Brun J., 2000).

6 Finally, as well as referring to actual facilities, the notion of resources can also be understood in a relative sense: urban resources can be seen in terms of potentially accessible supply. Securing and sustaining access to urban resources can be the object of strategies on diverse scales (household, community, individual), which are reflected by the inhabitants' residential and professional trajectories. Access, or lack of access, to these resources has a concrete impact on the exercise of citizenship in the community - a concept that has recently become central both in social activism and in public policies. How can such factors be objectivized, in order to feed into our understanding of the production of inequality and urban social dynamics in general?

7 Such questions are all the more crucial when they apply to urban settings where vulnerable groups form a large portion or a majority of the population. It is therefore quite meaningful that all submissions for this issue covered Southern territories where access to goods and services is a critical issue.

Beyond this common trait, contributors to this issue chose diverse angles to characterize urban resources and their associated policies: the qualification of urban spaces (issue 39); the practices of actors when faced with constraints arising from their status or place of residence (issue 39); mobility systems and their impact on the accessibility of resources within the city (issue 40); the interaction between individual trajectories and local resources (issue 40).

\section{The distribution of resources over the city: qualifying maturing urban spaces}

The first group of papers raises the issue of the distribution of resources across the city in terms of their density, shortages or accessibility: this factor is used to qualify urban spaces on the basis of the presence or concentration of resources, but also to understand the way these spaces are articulated to the rest of the city. These papers focus more specifically on intermediary and peripheral areas: in other words, these areas' evolutions are examined both from the perspective of their own resources, and from that of their residents' access to resources, both locally and within the city.

Using an essentially quantitative approach, Eugênia Viana Cerqueira jointly observes the potential of places through an assessment of urban facilities, and that of individuals through their economic resources. The author shows how both elements tend to add up: the gap in potential between places is reinforced by that between individuals, all the more acutely that these inequalities correspond to discrepancies in peoples' uses of transportation modes. The urban peripheries that developed in Belo Horizonte (Brazil) 
differ according to their population's socio-economic make-up, but also to their modalities of access to urban resources and mobility practices. The article highlights the dependency of the poorest towards the centre, and more generally the forced mobility for accessing resources. The social diversification of the suburbs thus reproduces - in a more complex manner but with the same level of intensity - the segregated urbanisation model.

11 Another approach to characterizing the situation of low-income peripheral areas in terms of access to urban resources is presented by Jean-François Valette in his study of the colonias populares of Mexico City (Mexico). Starting from the suburban population's mobility practices, the author looks at the urban resources that exist around a given place of residence. These are connected to factors that include the density of informal economic activity and the degree of integration to sociability networks, which is a function of land ownership as much as of social organisation. Analysing practices also makes it possible to qualify the ways in which residents have access to resources from the city centre or from neighbouring areas. The colonias populares are much more connected to the rest of the metropolis than one might think: the effects of relegation should therefore be reconsidered. Finally, the author highlights the diversity of practices on the neighbourhood scale: one same residential environment can be integrated to different location systems of very diverse scales, whether locally centred or on the contrary operating at a metropolitan scale. The author stresses how much urban practices and the development of urban skills are significant markers of social differentiation -from dependence or relative captivity towards one's local context through to multi-centric urban rooting.

The diversity of peripheral spaces is also at the heart of Vincent Berdoulay and Thi Thu Trang Ngo's reading of gender relations in Hô Chi Minh City (Vietnam). The authors focus on the dialectics between the potential resources women can draw upon to transform gender relations, and those that remain inaccessible to them because of gender relations. They show how access to employment is a key factor of evolution, as well as a major source of inequality between women depending on their employment status (salaried vs. informal work). Through the variations of social relations observed between types of habitats, the article documents a transitional space that responds to major sociological transitions currently occurring in Vietnam, where gender relations can also be redefined through urban resources: housing status, integration or conflict between work and domestic functions in the suburban context.

\section{Defining urban resources through informal practices}

13 Another way of defining urban resources is by analysing the practices of populations who are partly or entirely deprived of the status and protection granted by residence and in some cases by citizenship. This is the case with São Paulo's Bolivian and Paraguayan migrants, studied by Sylvain Souchaud, who join the garment manufacturing industry: an informal economic niche located at the centre of the metropolis. The trajectories of Bolivian and Paraguayan migrants are closely articulated with this sector, which provides them with a job and accommodation in the metropolis. However, this mediation operated by migration networks leaves little scope for individual integration into the host country's urban society. The author highlights the paradoxical nature of recent immigrants' experiences of the city: excluded from the 
job and housing markets because of their foreigner status, they pursue their migratory project through the migrant-specific resource provided by the manufacturing workshops.

Laurent Faret's article reflects the same ambivalence, with a study of Central American migrants' access to the urban environment in Mexico in extreme conditions. Most recent migrants have met obstacles in their migration project and have to tackle the metropolis and its resources on their own. The resources are able to access are, at least initially, specific to their circumstances as migrants. Migrants get in touch with associations that support them for the duration of their transit, whether permanent or not, and find support in the metropolis' characteristics. For instance, the interconnection of mobility networks on diverse scales (local, regional, national and international) serves their mobility strategies by enabling them to avoid police checks, while giving them direct access to crossing points on the Northern border. Due to the precariousness of their position in the city, these migrants' knowledge of local resources remains superficial, often restricted to a local scale and limited by the vulnerability of their status.

The informality of Rio de Janeiro's favelas (Brazil), examined by Rafael Gonçalves, can also provide an urban resource. By providing a stable habitat in relatively close proximity to economic centres, the informality of the favelas creates a unique urban fabric. With their versatile buildings and flexible occupancy models, the favelas can solve some of the many paradoxes of the metropolis, although most public policies fail to acknowledge these advantages. Without minimizing its ambiguity, the author shows the importance of the informal sector's resources and of the social complexity that characterizes it $-\mathrm{a}$ fact that needs to be taken into account by programmes that aim to formalising such practices.

All three articles illustrate how the only resources available to individuals who live in precarious circumstances (whether as city dwellers or as citizens) are often the urban resources themselves (centrality, functional versatility, transport hub and interface). For this reason, the authors point at the ambivalence of such situations: due to their lack of status, population groups can find themselves "captive" within a niche, which leaves them vulnerable and exposed.

\section{Urban resources, mobility and accessibility}

Understanding the distribution of resources over a city requires identifying the resources that contribute to their accessibility. Several articles in this issue address this question by investigating mobility systems, studying public policies in the light of the population's practices.

cities are examined from this perspective: Cape Town (South Africa), Bouaké (Mali) and Santiago (Chile). In spite of their distinct demographic, economic and historic contexts, the three cities are characterised by a high degree of pressure on the centre's resources, and by a weak or failing transport infrastructure that could provide improved accessibility for a large portion of the population. Jean-Michel Kouakou Attien depicts the concrete challenges affecting transport in the Ivory Coast's second city, Bouaké. The deterioration of existing services following the political crisis of 2002 was compensated by the emergence of a new service, both more flexible and more 
dangerous for users: motorbike taxis. Although this means of transportation is a necessity to overcome the obstacle of distance in a city of over 500,000 inhabitants, it is also a source of vulnerability for the urban population - another example of the ambivalence of a resource that remains accessible to the most deprived groups.

The centre/periphery dichotomy affects another practice in a very different context: the use of bicycles in Santiago, Chile. Claudia Arellano Yévenes and Fernando Saavedra Peláez show how one same mode of transport can be the expression of very diverse resources, depending on the place of residence. On the one hand, cycling can be a chosen alternative used by the residents of the centre for short-distance trips. On the contrary, for the peripheries' residents, its use can be a response to constraint and to the lack of an alternative for long-distant commutes. The city centre's facilities, which include segregated cycle lanes, reflect the public policies' contribution to unequal access.

The legacy of the apartheid regime in South Africa continues to weight heavily upon Cape Town's transport system, as analysed by Solène Baffi. Showing how transport networks and models have historically reflected the former segregationist regime's objectives, the author raises the issue of the realignment of public transport policies after the end of apartheid, questioning their ability to facilitate the population's sociospatial inclusion. The neoliberal model of public transport management that prevails in Cape Town and other cities has clearly improved the mobility potential of populations that rely on public transport. However, actual accessibility remains to be achieved for these populations, in particular by developing an intermodal and integrated system.

\section{Urban resources: between amenities and practices}

21 Access to urban resources does not only depend on their location within the city, or on the sole material conditions involved in reaching them. Other resources also come into play, which individuals might or might be able to muster. The last two articles focus on the combination of different types of urban resources in the insertion of national rural migrants into Mexico City's metropolitan area. Antonine Ribardière shows that although migrants are often supported by family members who migrated earlier on, their residential and professional trajectories do not fit within an organised system, and are not at the margins of mainstream urban society. Naucalpan, an industrial and residential suburb of Mexico City that has attracted migrants for decades, has a specific configuration that enables newcomers to meet both their employment and housing needs. Once they are more settled, migrants gradually emancipate themselves from the local context to access the metropolis' wider resources. Aurélia Michel points that the urban resources that these populations initially lack soon become the very target of their trajectory. The article compiles life stories that illustrate how these resources are acquired gradually and fluctuate with the families' decisions and projects, depending on whether those require access to the centre or on the contrary to local resources.

To conclude, we would like to highlight three angles of inquiry deriving from the findings of these articles, which could contribute to a more specific definition of urban resources.

First of all, the term refers to the spatial arrangement of resources. According to this more restrictive meaning, urban resources are the resources of the city: as we have seen, these are all the more crucial when they are the only resources available to 
legally, economically or socially vulnerable individuals who do not have access to public resources. Secondly transport systems, and therefore public policies, have a major impact on the relation between the layout of resources within the city and their accessibility for individuals of varying economic, social and political capacities. Thirdly, these resources take on a specifically urban dimension when they enable populations to take control of the urban environment, and therefore of the spatial arrangement of resources over the city. The notion of urban resources thus brings the focus on the inequalities that occur at the intersection of two processes: the way resources are arranged over the space of the city, and the way citizens can take ownership of these resources. Monique Bertrand concludes with an analysis of the contribution brought by the notion of urban resources through the questions raised by the articles in this issue.

\section{BIBLIOGRAPHY}

Authier J.- Y. (dir.) et al., 2001. Du domicile à la ville. Vivre en quartier ancien. Anthropos, coll. Villes, $214 \mathrm{p}$.

Bertrand M., 2010. Introduction. Revue Tiers Monde, $1 / 2010$ ( $\left.n^{\circ} 201\right)$, p. 7-23.

Bourdieu P., 1993. La Misère du monde. Ed. du Seuil, 956 p.

Fol S., 2010. Mobilité et ancrage dans les quartiers pauvres : les ressources de la proximité. Regards Sociologiques, $\mathrm{n}^{\circ}$ 40, p. 27-43.

Lévy J.-P., Brun J., 2000. De l'extension au renouvellement métropolitain : mosaïque sociale et mobilité. In Dureau F., Dupont V., Lelièvre E., Lévy J.P., Lulle T. (éd.), 2000. Métropoles en mouvement : une comparaison internationale. Paris, Anthropos-IRD, coll. Villes, p. 229-246.

WenglenskIi S., 2010. Accès à l'emploi : champ des possibles contre champ des pratiques. In Massot M.H. (dir.). Mobilités et modes de vie métropolitains. Paris, L'Oeil d'or, p. 121-137.

\section{NOTES}

1. Monique Bertrand notes: "While mobility was once understood as a mere vehicle towards territorialised resources and connected to territorial planning, it is now perceived as a resource in its own right, in and from the city" (Bertrand, 2010).

2. For instance, Sylvie Fol highlights the importance of local resources for low-income groups (Fol, 2010).

3. Bourdieu describes the profits of localization in the chapter "Site Effects " of The Weight of the World (Bourdieu, P., 1993, translated by Pricilla Parkhurs Ferguson, Stanford University Press, 1999).

4. These contextual effects are described for instance by Authier J.- Y. (ed.) et al. (2001). 
INDEX

Subjects: Sur le Champ - Sur le Terrain 